Lanas, Maija. (2017) An Argument for love in intercultural education in teacher education. Intercultural Education. 28(6), 557-570, DOI: 10.1080/14675986.2017.1389541

\title{
An argument for love in intercultural education in teacher education
}

\begin{abstract}
This paper proposes rethinking intercultural education in teacher education, arguing that any discussion of student teachers' intercultural education should be connected more explicitly to a theoretical conceptualisation of love. The first part of the paper focuses on identifying discursive boundaries in engaging with intercultural education in teacher education. It is established that if we are to develop intercultural education, we need consciously to move away from some discourses in teacher education, namely instrumentalism, performance-orientation, emotionlessness and seeing the relationship between teacher and learner as static. The second half of the paper develops a theoretical alternative by engaging with the concept of love as a basis for intercultural education in pursuing an alternative to the instrumentalist, performancebased, non-emotional fixed-relationship ethos of intercultural education in teacher education.
\end{abstract}

Keywords: intercultural education, emotions, love, teacher education, post-structuralism, education 


\section{An argument for love in intercultural education in teacher education}

\section{Introduction}

In the past year, in many international contexts, questions about intercultural education have become more relevant than ever. As continents, nations, groups and individuals formulate their reactions to increasing immigration from south to north, intercultural educators must ask: What does this development ask of us? How can our work best respond to the harmful conflicts emerging? This paper is a part of a special issue focusing on how we can adapt intercultural education to respond to contemporary forms of injustice. This paper focuses on intercultural education in teacher education.

I will argue that the manner in which intercultural education is currently framed in teacher education does not adequately respond to the needs of society, moreover, I will argue that is has never responded to such needs. Such an argument finds support in well-known existing literature that reveals that despite possible short-term positive impacts, intercultural education in teacher education programmes demonstrates a lack of translation to school practices (e.g. Cochran-Smith and Zeichner 2005, 21-22; Mills and Ballantyne 2010). The lack of transition has often been explained in terms of a mismatch between theory and public opinion (Martin 2010), in terms of the predispositions of student teachers (Gay 2010; Lortie 1975; Mills and Ballantyne 2010) and in terms of student teachers' beliefs about their own colour-blindness and neutral racial positions (Bell 2002; Leach 2011). In addition, it has been noted that the programmes themselves often highlight and address celebratory rather than critical approaches to diversity, employing "add-on" or piecemeal approaches (Mills and Ballantyne 2010; Schoorman and Bogotch 2010a; Schoorman and Bogotch 2010b). As an ongoing response to the identified lack of translation to practice, researchers and practitioners are inventing new means to reach the goals of intercultural education more efficiently, listing the goals of intercultural education on an individual and a school level (see for example Banks 2002; Leonard and Leonard 2006; Milner 2010), developing models of teaching and learning intercultural education (Baskerville 2011; Garmon 2004; Laughter 2011; Martin 2010; Phillion and Ming 2004; Scoffham and Barnes 2009), and discussing preservice and 
in-service teachers' perceptions of it (see for example Alviar-Martin and Ho 2011; Kaplan, AbuSa'ad and Yonah 2001).

Such literature provides intercultural educators with a growing body of new knowledge, methods and understanding. However, there is also a challenge in that in the literature the goals of intercultural education are commonly (but not always) presented as "a priori" - something that can be predetermined, top-down, on students, and measured and evaluated - and not as something that should be agreed in dialogue with the students. There is a risk that such a top-down presentation of goals has turned intercultural education away from its greatest strength of re-imagining the possibilities of social justice. We should not see intercultural education as a forum for transmitting intercultural knowledge and competences, and for measuring the effects of such transmissions, but as a forum in which we can imagine new possibilities for social justice. A forum for engaging with the emerging issues of each historical moment, such as the growing wealth inequality around the world, crises involving refugees, growing Islamophobia, anti-immigrant sentiment should be a forum not for telling but for listening, re-imagining and re-inventing.

The goal of intercultural education can be simply defined as "facilitat[ing] conscientisation among teachers that would inspire efforts towards changing (rather than preserving) the status quo" (Schoorman and Bogotch 2010, 1042). Rather than a body of knowledge to be transmitted, it should be seen as a "poetic experiencing of contradictions in order to invent new modes of subjectivity for both teacher and student" (Wang 2005, 59). Thus, intercultural education is something that is impossible to teach as such (Wang 2005, 59), but rather students must learn to understand the processes through which they are made subject, so that they "are better positioned to resist particular forms of subjectivity, and thereby actively choose to think and do things differently" (see also Davies and Banks 1995, 46). This means that students of intercultural education are asked to enter the "zone of discomfort" (Zembylas 2010) (which is a challenging yet positive state), and engage with what Britzman (1998) calls "difficult knowledge", which refers to the kinds of knowledge that require us to rethink the world, ourselves and others in it. For example, for mainstream students, difficult knowledge may constitute knowledge of power and privilege. Difficult knowledge asks students to overcome biases, and biases cannot be overcome by external imposition. Thus, intercultural education asks students to engage in a process of "self-shattering" (Pinar 2004), and to rethink not only the world around them but also themselves in the world. Therefore, intercultural education is, at times, discomforting and painful. Teacher education, as an 
ideological and discursive structure, does not usually provide spaces for working with this discomfort.

This paper is divided into two parts. The first part focuses on establishing intercultural education as representative of the kind of learning that does not easily fit into the existing discursive structures of teacher education (see also Lanas 2014), and on analysing teacher education as a discursive context for intercultural education. It will be established that if we are to develop intercultural education for teachers, we need to consciously move away from top-down approaches and some discourses in teacher education, namely instrumentalism, performance-orientation, emotionlessness and seeing the relationship between teacher and learner as static. These fail to produce new subjectivities and new possibilities for social justice.

The second half of the paper will develop a theoretical alternative, attempting to bring love into intercultural education. The theories and discourses with which we frame our teaching either enable or shut off different outcomes. Theorising matters, as "Not only do people produce theory, but theory produces people...different theories of the subject make possible different lives" (St Pierre 2001, 142). Since intercultural education is painful, we should engage with it through promoting connections such as intimacy, kindness and compassion (Wang 2005, 54; Zembylas 2007). "While we can never be certain about the whole truth or ultimate ends, we can make sure that the actual means we use to contribute to social justice are as moral, nonviolent and loving as possible" (Chabot 2008, 817). Therefore, the second half of the paper will engage with the concept of love as a basis for intercultural education, in the hope of providing an alternative to the existing ethos in intercultural education in teacher education.

In developing a loving intercultural education, I draw on Lanas and Zembylas (2014) and Chabot (2008), who view love as a rigorous, transformative and revolutionary force. Whereas love is commonly seen and treated as a soft, wishful and romanticised ideal - with such treatment usually utterly lacking in theoretical rigour - this is not my approach. The approach to love provided in this paper is not based on wishful or romanticised ideas of intercultural education, but rather on the social reality that the means we use are part and parcel of what is being produced.

The grounding argument of the paper is twofold: 1) We cannot discuss intercultural education without attending to the discursive context in which intercultural education takes place. 2) If we 
are to contribute to a loving society, we must purposefully develop rigorously loving responses in and through intercultural education.

\section{Teacher education presents discursive challenges to intercultural education}

Teacher education incorporates powerful discursive practices with which students have socialised, and that impact the manner in which students approach new theories and new knowledge during their education. These existing discursive practices are likely to dominate the perceptual awareness of student teachers, which has implications for what they might learn, what they might become and what they might expect of others (Sumara, Davis and Iftody 2008, 170). Four prevalent discourses are especially troublesome for intercultural education that aims, as described above, to inspire efforts to change the status quo, to invent new modes of subjectivity for both teacher and student and to imagine new possibilities for social justice. These four discourses are so familiar to us that they seem common sense, but they are discourses like any other discourses, and should be thought of as such. These are instrumentalist ethos, performance orientation, lack of focus on emotions and the predefined relationship between the teacher and the learner. I will present each below.

\section{Instrumentalist ethos}

There is an ongoing instrumentalist ethos in teacher education that stresses questions of "proper" preparation, immediate use and apparent relevance (Phelan et al. 2006; Phelan 2011). Teacher education with instrumentalist ethos lacks the everyday spaces to produce new knowledge. Segall $(2008,17)$ calls this the challenge of "reading without writing", and explains that student teachers do not tend to think of themselves as theorists or theoretical reflectors, but rather as practitioners who are merely required to implement theories generated by others. Student teachers accustomed to the instrumentalist discourse imagine they will learn what truths to teach and how to teach those truths (Phelan 2011; Taguchi 2007, 278-279). Consequently, student teachers often feel that they have not learned anything if they are unable to apply their "learnings" directly. The instrumentalist focus also directs teachers and researchers to attempt to "solve the problem" of unsuccessful intercultural education by inventing new formulas or models to transmit knowledge. Intercultural topics, on the other hand, tend essentially to have no clear-cut answers and easy applications. 
Reflecting on intercultural topics requires retaining complexities, accepting multi-vocality, openness and the questioning of fixed truths. As discussed above, intercultural education in teacher education is not simply a forum for teaching the skills needed to re-imagine new possibilities for social justice, but a forum where that re-imagination can occur, and where both teacher educators and student teachers encounter multiple others, engage in difficult knowledge and explore the zone of discomfort to re-imagine the world in which they live. If both educators and students expect the answers to be readily "out there" to be found, transmitted, learned and applied, intercultural education will serve to uphold the status quo, "producing and sustaining predictable, stable and normative identities and curricula" (Phelan 2011, 214), and not inventing new subjectivities or imagining new possibilities for social justice. This is only achievable by engaging in a dialogue that is not limited by predetermined instrumentalist goals.

\section{Performance orientation}

Teacher education is often performance oriented. In many international contexts, the school performance of both students and teachers is measured, and education is thus based on the idea that both (more or less) must aim to perform their role as well as possible. Depending on the variety of means of measurement used, students and teachers learn what is expected of them in their role. At worst, students learn to perform learning, and teachers teaching, without the actual pursuit of learning or teaching (see also Zeichner 2010), or to perform reflectivity rather than reflecting (Atkinson 2012). In a performance-oriented discursive context, "professionalism" becomes characterised as something assessable from the outside, something that is acquired, measurable and inherently prepared. A teacher may feel pressure to exhibit professionalism by performing preparedness, and a teacher who feels unprepared in a situation may question his or her own professionalism. In such a situation, a teacher may prefer to actively negate and refuse new knowledge; they will break the theory before it has a chance to break the learner (see also Britzman 2003, 86; Segall 2008, 18). On the other hand, intercultural education that aims to invent new modes of subjectivity and to imagine new possibilities for social justice is never "ready".

For intercultural education, the idea of professionalism as something "ready", combined with the instrumentalist belief in pre-existing solutions that simply need to be "found", creates a challenge. Any teacher's multicultural "competence" is fundamentally something that can never be "ready" and fixed, but requires reflexivity, relearning and dialogical re-seeking with each new other. 
Professionalism is characterised as being engaged in a continuous process of becoming, as essentially unfinished. Such authentic dialogical seeking can only occur if one does not consider one's professionalism as already "finished", but constantly open to new imaginings of social reality. If we perceive intercultural education simply as "successful" or "unsuccessful" based on the empirically testable outcomes in teachers, students or schools, and if we see intercultural knowledge as knowledge some have and others lack, intercultural education turns away from its greatest strengths, namely the beauty, painfulness and potential of re-imagining the world and ourselves in it. In intercultural education, the shared search process itself is the only possible "solution".

\section{Lack of focus on emotions}

Knowledge tends to be perceived as emotion-free and essentially painless. There are no structures in place in education to recognise, accept and work with difficult emotions or to accept the painfulness of learning. In general, experiencing pain in connection with learning is experienced as unjustified (Wang 2008, 12), causes a sense of alarm and may be interpreted as a signal that something is wrong. Consequently, expressing negative emotions tends to be seen as inappropriate in education (Lanas 2011; Lanas and Corbett 2011). Overall, emotions are often seen as separate from rationality and our intentional selves, as forces that influence us from the outside (Zembylas and Fendler 2007) and things that should be "managed" away.

Intercultural education, on the other hand, constitutes a process in which all kinds of emotions are essential and must be addressed openly. As an increasing amount of researchers and theorists of emotion suggest, emotions are bound inherently with productive power and societal issues. Although we commonly experience our emotions as personal, private and partly what make us "us", those very emotions are also socially constructed and shared (Ahmed 2004a, 2004b; Game 1997; Gray 2008). Emotions work to link our personal selves to broader societal issues (Zembylas 2007c). They are products of previous experiences, influenced by social, historical and cultural contexts, and, much like habitus (Bourdieu 1984), embody history as being internalised as a "second nature" and thereby forgotten as history (Zembylas 2007b). Therefore, emotions reflect societal power relations and are also significant in the actual formation and maintenance of social identities and collective behaviour (Zembylas 2007b). This means that difficult emotions occurring in intercultural education do not "reside within" students, but within a broader societal context. 
Therefore, rather than for example painting a simple negative or positive image of students' emotional responses to intercultural issues, we should examine how emotions relate to intersecting discourses and inform actions when negotiating the presence of the other and one's sense of belonging (Zembylas 2012). The deconstruction of emotional rules -specifically, who is allowed to perform what emotions - is central when engaging with difficult topics.

\section{Predefined relationship between teacher and learner}

In education, teachers and students are commonly placed in fixed roles in which their possible subjectivities are limited, and deviations from these roles may bring the entire relationship into question. These roles may vary somewhat in different contexts, but they are quite commonly characterised by the idea that competence or knowledge is something the teacher has and the student lacks, and by the assumption that the teacher does the teaching and the student the learning. Consequently, learning is seen as a process that occurs within students, not within the teacher, and the teacher is commonly portrayed as a spectator (facilitator, supporter, observer, evaluator) in the process. When the educational relationship is viewed in this way, the roles of "teacher" and "learner" comprise a power relationship that allows teachers to withdraw to power positions at a painful moment (Keith 2010). Teachers may do so because it provides a comfortable escape route from difficult emotions, or because they may feel the emotional rules obligate them to appear in control in their role, and they may not feel they have the right to experience difficult emotions (Keith 2010). In intercultural education, in turn, teachers and students should be able to step out of their comfort zones into an uncertain, intersubjective space vibrant with new possibilities (Wang $2005,56)$

When we ask students to think and engage in a "self-shattering" process, the teacher educator's own sense of self should not be privileged (Wang 2005), and this is not pedagogically sensible or ethically sustainable. In addition, many who have taught intercultural education know from experience that when a student teacher engages with difficult knowledge, the teacher-educator enters a zone of discomfort. In these situations, if teacher and learner subjectivities are fixed and static, only the self of a learner is in play, while the teacher's self may be hidden behind the protective walls of professionalism. Wang (2005) notes that such a position is untenable, and asks a key question: How can unsettling students' identities not be accompanied by a questioning of teacher educators' own socially, politically and culturally situated selves? Such a position is also 
unfruitful. Accepting the fractures in the roles of teacher and learner is a crucial requirement for the emotional process of engaging with difficult knowledge together. Opening up the categorical separation between teachers enables educators to explore the zone of discomfort with students. The topics discussed in intercultural education classes are the kind in which the teacher educator's self is also at play, even if it is concealed behind the wall of professionalism. For example, Keith (2010) describes the painful experience of being grouped with "the white oppressor" by a student. The willingness on a teacher's part to be influenced by communal inquiry is required for a democratic process in which the voices of students are heard without being judged, even when those voices bring the teacher anger, frustration and anxiety (Wang 2008, 15). At best, such situations become instances in which teachers and students call upon each other to move beyond the familiar toward new landscapes of subjectivity (Wang 2005, 54).

To conclude, theory is a means for thinking in, with and about one's practice as a teacher. The prevalent discourses in teacher education - instrumentalist ethos, focus on performance, lack of awareness of emotions and the predefined relationship between teacher and learner - also work to produce instrumentalist, non-emotional, performance-based responses with a static perception of relationships. If we wish to change these responses in intercultural education, we must begin by changing the discursive paradigm of intercultural education in teacher education. If we are to develop genuinely new practices in education, we need to think about practice in terms of new theory.

\section{Engaging with love in intercultural education}

I suggest moving intercultural education from a performative-instrumentalist realm of acquiring competences to a realm of love that allows for developing new ethical responses in practice. Love, as Lanas and Zembylas (2014) argue, entails six perspectives: love as an emotion, love as choice, love as response, love as relational, love as political and love as praxis.

First, love is an emotion. Love, like any emotion, is not just "there", but it is embodied and performative (Ahmed 2004; Thien 2005; Zembylas 2007b). In other words, love does not simply "exist"; it is brought into existence by "doing" it. Although love is an emotion, it is not necessarily a feeling; this is to say that it does not always feel nice and cosy, and affection is not necessary for active love (Hinsdale 2012, 43). As an emotion, love is also not "pure", as it is not clean of other 
emotions nor is it purely ethical. Engaging with love in intercultural education entails vulnerability and a risk; if I invest my Self, if I respond in loving ways to the other and if the other does not respond in a loving way, I hurt. Thus, love, as an educational response, is not a safe haven, the choosing of which would alleviate discomfort. Rather, it is a way to respond to such discomfort. Responding with love does not mean repressing other emotional responses to alienation like fear, shame, anger, hatred or despair (Liston 2000), but when we choose to love, we choose to move against fear, alienation and separation (Hooks 2000, 93). Commitment to love as an educator requires courage and commitment in the face of inevitable feelings of hatred, anger, fear and despair (Chabot 2008, 813).

Second, love is a choice we make voluntarily; it is not something that is handed to us from the outside, nor is it something that exists inherently inside us. Instead, it is an attitude that we willingly cultivate toward others (Oliver 2001). Even when we choose to love, it is a decision that must be constantly reaffirmed (Oliver 2001, 220-21). Love is not something we choose permanently, but something that requires re-choosing every time we direct a response to the surroundings. It is constituted moment to moment by the responses we choose to give.

Third, love is a response. Here, a loving response is not understood as an abstract and ahistorical metaphor pursuing a false connection, but instead the ethical agency motivates a move toward others (Hinsdale 2012, 39; Oliver 2001). Seeing love as a response to others links it to the relational perspective of Self. We "come into being" as subjects each moment as we respond to the world. This means that our selves are connected profoundly to, rather than separated from, one another. Our "own subjectivity depends on how we respond to others" (Hinsdale 2012, 38). We do not choose whether we respond or not (even inaction and silence constitutes a response), but we do have a choice in how we respond (Lanas 2011). In choosing how to respond to others, we are choosing who we are in any moment (Hinsdale 2012, 42), and we limit and open up possible subjectivities for those others. We have an ethical responsibility to respond in ways that open up rather than close off the possibilities of response for others (Oliver 2001, 18). If we, as teachers of intercultural education, accept and act upon the responsibility for our responses that play a part in the "coming into being" of others, then we are giving loving responses. Acknowledging this ethical responsibility constitutes a loving response.

Fourth, love is essentially relational (Berlant 2011, 684; Irigaray and Martin 1996; Jackson 1993; Morrison, Johnston and Longhurst 2012, 10; Sedwick 1999). It is neither a subjective experience 
nor a personal ambition, but a "loving dialogue and relationships with other people, other communities, other parts of the world and other living creatures" (Chabot 2008, 820). Love as relational means it is not something that can be treated as given, essential and buried deep within us, but "manifests differently in different spaces and places" (Morrison et al. 2012, 8). Chabot (2008, 809) distinguishes five types of human relationships, only one of which entails love: (1) self against others (competition), (2) self without others (isolation), (3) self for others (charity), (4) self with others (coordination) and finally (5) self with self (love). Love, as a self-self relationship, entails a choice to connect, to find a Self in the other (Hooks 2000, 93). At least three facets seem necessary for loving connections, according to Liston (2000): a diminished sense of self, an attentive gaze toward the situation and the other and a presumption that "good" exists and is the object of love. This means non-sovereignty, transcending the Self.

Fifth, love is political, influenced by social, historical and cultural contexts (Zembylas 2007), significant in the formation and maintenance of political and social identities, and in collective behaviour. Love, argues Ahmed (2004), moves us "towards" something and bonds people together. In the same manner, if love is seen as an attachment to one's own kind, it may lead to hatred for others; thereby, it is crucial to acknowledge love as political while still striving toward a conceptualisation that is not immediately associated with attachment and to the forming of an "us". A politics of love entails the possibility of love as a site for collective becoming (Berlant and Hardt 2011).

Finally, love is praxis; love is as love does. It is both an intention and an action (Hooks 2000, 45; Nash 2013; Oliver 2001). While we cannot reduce love to any specific acts, Chabot $(2008,813)$ names some of the acts that characterise love, such as voluntary acts of care, responsibility, respect and knowledge. In addition, loving acts are characterised by the will to give. Giving is a productive act that enhances the joy, insight and ability of the giver and the receiver (Chabot 2008, 812). The relational nature of love means that what constitutes "loving acts" depends on the other and the context.

Engaging with love in intercultural education changes how we approach teaching and learning. In loving responses, whether we like it or not, we are all learners and each other's teachers (Lanas 2014). In contrast, within the performance-instrumentalist realm, intercultural knowledge is perceived as something a teacher has and students lack (and that should be transmitted to the students through teaching). In the realm of love, teacher educators and student teachers no longer 
have fixed roles that carry different ethical obligations, and an educator is no longer automatically inscribed as "more interculturally aware". Our loving responses are not determined according to some external criteria, but they "come into being" in the relationship in question. This means that as a teacher-educator, I am only as loving as I am in my relationship with my various students, who are also my teachers. Similarly, in their future occupation, my students are only as loving as they are in their relationships with their various pupils, who are also their teachers. Love comes to be redefined and reassessed in each relationship, and striving for love forces us to listen to the other more carefully while considering a question: "How can I be more loving in my relationship with this particular other?"

In addition, placing an emphasis on love invites us to ask less instrumental questions, such as "How can one engage with painful knowledge without inducing further pain?" and "How may one recognise in education historical, societal or global violence without the learning experience reflecting this violence?" While intercultural education may be essentially painful, a focus on love emphasises that it need not be experienced as violent.

\section{Implications for intercultural education}

In this paper, I have argued that as a discursive context, teacher education fundamentally contradicts the goals of intercultural education, and if we are to develop intercultural education that could be claimed to be "successful", we should engage in a critical reflection of teacher education, assess how loving our approaches are - and also redefine what we mean by success or effective

Intercultural education in teacher education might benefit from shifting attention from outcomes "out there" in field schools to the processes that take place "in here" in teacher education, and seeing these processes as outcomes in themselves. Instead of asking how to change the responses "out there", we could ask: how are we re-imagining loving responses "in here"? To explain, if we locate the goals of teacher education "out there" in the field schools, and if, in the field schools, they accordingly locate their goals "out there" in the "real lives" and futures of the students, we find ourselves in an ever-spiralling cycle of education in which the goals are always somewhere else, inherently unreachable. Intercultural education might be seen as responding, with love, in the moment and creating spaces for new such responses. 
No matter how idealist it sounds, we can best teach love by learning together to be loving in our responses to the other - both the other within us and the one facing us. With each new learner and new difficult emotion, we must re-learn what love means. Intercultural education consists of the relentless and constant efforts to open up safe spaces for students' responses and to respond in a range of circumstances to the various frightened, frightening, angry, provoking, passive and excited students in thoughtful ways that open up new subjectivities and new previously unimaginable pathways for thinking and acting. When engaging with difficult issues associated with love, educators must tolerate their own discomfort and the discomfort of others. The task of the teacher when teaching discomforting topics might then be characterised as situationally figuring out how to assist the process of 'becoming' at the face of discomfort, so to relieve the violence of the experience. There is nothing soft or romantic about it; instead, it is rigorous reflexive work that requires professional care and expertise.

If we wish to bring love into the historical moment in which we live, students and educators must be asked to implicate their own teaching with new theory, to examine the theories they already hold and to re-theorise their teaching and their practicum environments (Klein 2012; Segall 2008; Taguchi 2007). As teacher educators and as intercultural educators, we must ask ourselves: "Do my approaches build on love or on violence?" "Do my goals contribute to re-imagining the world or to upholding the existing one?" I argue that any pedagogy or any education pursuing to add love must be based on love.

Love, like any theory, is at its worst seen as a catechism, a set of repeatable moral precepts, a mode of preventing thought (drawing on Barcan 2003, 351-52). At best, the theory of love is the provoker of questions, the opener of minds, and provides nuanced and insightful ways of understanding the world. Thinking in terms of love provides teacher educators and researchers of teacher education with alternatives for the instrumentalist and performative pressures. We can do little to diminish these pressures and, indeed, this paper does not suggest that diminishing them should be the goal. On the contrary, it suggests that as part of intercultural education we should acknowledge the occasional mismatch between intercultural education and the performative, instrumentalist pressures influencing teacher education, and we should respond to them and amidst them in our everyday practice in loving ways. 
In the current global and societal climates, it seems loving responses are rare, and intercultural education in teacher education does little to change this. Love is like a muscle in need of training. Loving responses do not just "happen”, but instead must be taught and learned.

\section{References}

Ahmed, Sara. 2004a. "Collective Feelings: Or, the Impressions Left by Others." Theory, Culture \& Society 21 (2): $25-42$.

—. 2004b. The Cultural Politics of Emotion. Edinburgh: Edinburgh University Press.

Alviar-Martin, Theresa and Li-Ching Ho. 2011. “'So, where do they fit in?' Teachers' Perspectives of Multi-cultural Education and Diversity in Singapore." Teaching \& Teacher Education 27 (1): 127-35. doi: 10.1016/j.tate.2010.07.009

Atkinson, Becky. 2012. "Strategic Compliance, Silence, 'Faking It', and Confession in Teacher Reflection.” Journal of Curriculum Theorizing 28 (1): 74-87.

Banks, James A. 2002. An Introduction to Multicultural Education ( $3^{\text {rd }}$ ed.). Boston, MA: Allyn and Bacon.

Barcan, Ruth. 2002. "Problems Without Solutions: Teaching Theory and the Politics of Hope." Journal of Media \& Cultural Studies 16 (3): 343-56. doi:10.1080/1030431022000018708

Baskerville, Delia. 2011. "Developing Cohesion and Building Positive Relationships Through Storytelling in a Culturally Diverse New Zealand Classroom.” Teaching \& Teacher Education 27 (1): 107-15. doi:10.1016/j.tate.2010.07.007

Bell, Lee Anne. 2002. "Sincere Fictions: The Pedagogical Challenges of Preparing White Teachers for Multicultural Classrooms.” Equity \& Excellence in Education 35 (3): 236.

Berlant, Lauren. 2011. “A Properly Political Concept of Love: Three Approaches.” Cultural Anthropology 26 (4): 683-91.

Berlant, Lauren and Michael Hardt. 2011. "No One is Sovereign in Love: A Conversation Between Lauren Berlant and Michael Hardt." Amour 18. http://nomorepotlucks.org/site/no-one-issovereign-in-love-aconversation-between-lauren-berlant-and-michael-hardt. Accessed May 29, 2013.

Biesta, Gert. 2003. "Learning from Levinas: A Response.” Studies in Philosophy \& Education 22 (1): $61-68$.

Bourdieu, Pierre. 1984. Distinction: A Social Critique of the Judgement of Taste. London: Routledge \& Kegan Paul. 
Britzman, Deborah P. 1998. Lost Subjects, Contested Objects: Toward a Psychoanalytic Inquiry of Learning. Albany: State University of New York Press.

-. 2003. After-education: Anna Freud, Melanie Klein and Psychoanalytic Histories of Learning. Albany: State University of New York Press.

Chabot, Sean. 2008. “Love and Revolution.” Critical Sociology 34 (6): 803-28.

Cochran-Smith, Marilyn and Kenneth Zeichner. 2005. Studying Teacher Education: The Report of the AERA Panel on Research and Teacher Education. Mahwah, NJ: Lawrence Erlbaum.

Davies, Bronwyn and Chas Banks. 1995. “The Gender Trap: A Feminist Poststructuralist Analysis of Primary School Children's Talk About Gender." In Debates and Issues in Feminist Research and Pedagogy: A Reader, edited by Janet Holland and Maud Blair, 45-69. London: The Open University.

Game, Ann. 1997. "Sociology's emotions." Canadian Review of Sociology/Revue Canadienne De Sociologie 34 (4): 385-99. doi: 10.1111/j.1755-618X.1997.tb00215.x

Garmon, M. Arthur. 2004. "Changing Preservice Teachers' Attitudes/Beliefs About Diversity." Journal of Teacher Education 55 (3): 201-13. doi: 10.1177/0022487104263080

Gay, Geneva. 2010. “Acting on Beliefs in Teacher Education for Cultural Diversity.” Journal of Teacher Education 61 (1/2): 143-52. doi:10.1177/0022487109347320

Gray, Breda. 2008. "Putting Emotion and Reflexivity to Work in Researching Migration." Sociology 42 (5): $935-52$.

Green, Bill and Jo-Anne Reid. 2008. "Method(s) in our Madness? Poststructuralism, Pedagogy and Teacher Education.” In Critical Readings in Teacher Education: Provoking Absences, edited by Ann Phelan and Jennifer Sumsion, 17-31. Rotterdam: Sense Publishers.

Hinsdale, Mary Jo. 2012. “Choosing to Love.” Paideusis 20 (2): 36-45.

Hollins, Etta R. and Maria T. Guzman. 2005. "Research on Preparing Teachers for Diverse Populations." In Studying Teacher Education: The Report of the AERA Panel on Research and Teacher Education, edited by Marilyn Cochran-Smith and Kenneth Zeichner, 477-548. Mahwah, NJ: Lawrence Erlbaum.

Holquist, Michael. 1990. Dialogism: Bakhtin and His World. London: Routledge.

Hooks, Bell. 2000. All About Love: New Visions. New York: William Morrow and Company, Inc. Irigaray, Luce and Alison Martin. 1996. I Love to You: Sketch for a Possible Felicity in History. New York: Routledge.

Jackson, Alecia Youngblood. 2004. "Performativity Identified.” Qualitative Inquiry 10 (5): 673-90. doi: $10.1177 / 1077800403257673$ 
Jackson, Stevi. 1993. "Love and Romance as Objects of Feminist Knowledge." In Making Connections: Women's Studies, Women's Movements, Women's Lives, edited by Mary Kennedy, Cathy Lubelska and Val Walsh, 39-50. London: Taylor \& Francis.

Joldersma, Clarence W. 2011. "Education: Understanding, Ethics, and the Call of Justice." Studies in Philosophy \& Education 30 (5): 441-47. doi:10.1007/s11217-011-9246-7

Kaplan, Avi, Ismael Abu-Sa'ad and Yossi Yonah. 2001. "Jewish-Arab Relations in Israel: Perceptions, Emotions, and Attitudes of University Students of Education.” Intercultural Education 12 (3): 289-307. doi:10.1080/14675980120087499

Keith, Novella. 2010. "Getting Beyond Anaemic Love: From the Pedagogy of Cordial Relations to a Pedagogy for Difference." Journal of Curriculum Studies 42 (4): 539-72. doi:10.1080/00220270903296518

Klein, Mary. 2012. "How Inconvenient Assumptions Affect Preservice Teachers' Uptake of New Interactional Patterns in Mathematics: Analysis and Aspiration Through a Bifocal Lens." Educational Studies in Mathematics 80 (1): 25-40. doi:10.1007/s10649-012-9390-1

Lanas, Maija. 2011. Smashing Potatoes: Challenging Student Agency as Utterances. Oulu: University of Oulu.

—. 2014. "Failing Intercultural Education? 'Thoughtfulness' in Intercultural Education for Student Teachers." European Journal of Teacher Education $37 \quad$ (2): 171-82. doi:10.1080/02619768.2014.882310

Lanas, Maija and Michael Corbett. 2011. "Disaggregating Student Resistances: Analysing What Students Pursue With Challenging Agency.” Young 19 (4): 417-34.

Lanas, Maija and Michalinos Zembylas. 2014. "Towards a Transformational Political Concept of Love in Critical Education." Studies in Philosophy and Education 34 (1): 31-44. doi:10.1007/ s11217-014-9424-5

Laughter, Judson C. 2011. "Rethinking Assumptions of Demographic Privilege: Diversity Among White Preservice Teachers." Teaching \& Teacher Education 27 (1): 43-50. doi:10.1016/j.tate.2010.07.001

Leach, Linda. 2011. “I Treat All Students as Equal': Further and Higher Education Teachers' Responses to Diversity." Journal of Further \& Higher Education 35 (2): 247-63. doi:10.1080/0309877X.2010.548858

Leonard, Pauline and Lawrence Leonard. 2006. "Teachers and Tolerance: Discriminating Diversity Dispositions.” The Teacher Educator 42 (1): 30-62. doi:10.1080/08878730609555392 Liston, Daniel. 2000. “Love and Despair in Teaching.” Educational Theory 50 (1): 81-102. Lortie, Dan C. 1975. School-teacher: A Sociological Study. Chicago: University of Chicago Press. 
Martin, Kathleen J. 2010. "Student Attitudes and the Teaching and Learning of Race, Culture and Politics." Teaching \& Teacher Education 26 (3): 530-39. doi:10.1016/j.tate.2009.06.018

Mills, Carmen and Julie Ballantyne. 2010. "Pre-service Teachers' Dispositions Towards Diversity: Arguing for a Developmental Hierarchy of Change." Teaching \& Teacher Education 26 (3): 44754. doi: 10.1016/j.tate.2009.05.012

Milner IV, H. Richard. 2010. "What Does Teacher Education Have to do With Teaching? Implications for Diversity Studies." Journal of Teacher Education 61 (1/2): 118-31. doi:10.1177/0022487109347670

Morrison, Carey-Ann, Linda Johnston and Robyn Longhurst. 2012. "Critical Geographies of Love as Spatial, Relational and Political." Progress in Human Geography 37 (4): 505-21. doi:10.1177/0309132512462513.

Oliver, Kelly. 2001. Witnessing: Beyond Recognition. Minneapolis: University of Minnesota Press. Phelan, Anne M. 2011. "Towards a Complicated Conversation: Teacher Education and the Curriculum Turn." Pedagogy, Culture \& Society 19 (2): 207-20. doi:10.1080/14681366.2011.582257

Phelan, Anne M., Russell Sawa, Constance Barlow, Deborah Hurlock, Katherine Irvine, Gayla Rogers and Florence Myrick. 2006. "Violence and Subjectivity in Teacher Education." AsiaPacific Journal of Teacher Education 34 (2): 161-79. doi:10.1080/13598660600720561

Phillion, JoAnn and Ming Fang He. 2004. "Using Life-based Literary Narratives in Multicultural Teacher Education.” Multicultural Perspectives 6 (3): 3-9.

Pinar, William F. 2004. What is Curriculum Theory? Mahwah, NJ: Lawrence Erlbaum.

Schoorman, Dilys and Ira Bogotch. 2010a. "Conceptualisations of Multicultural Education Among Teachers: Implications for Practice in Universities and Schools." Teaching \& Teacher Education 26 (4): 1041-48. doi:10.1016/j.tate.2009.10.047

—. 2010b. "Moving Beyond 'Diversity' to 'Social Justice': The Challenge to Re-conceptualize Multicultural Education." Intercultural Education $21 \quad$ (1): 79-85. doi:10.1080/14675980903491916

Scoffham, Stephen and Jonathan Barnes. 2009. "Transformational Experiences and Deep Learning: The Impact of an Intercultural Study Visit to India on UK Initial Teacher Education Students.” Journal of Education for Teaching 35 (3): 257-70. doi:10.1080/02607470903091294

Sedwick, Eve. 1999. A Dialogue on Love. Boston: Beacon Press.

Segall, Avner. 2008. "Why Teaching Critical Social Theory as Theory Might Not be Enough." In Unsettling Beliefs: Teaching Theory to Teachers, edited by Robert J. Helfenbein and Josh Diem, 15-29. Charlotte, NC: Information Age. 
St Pierre, Elizabeth Adams. 2001. "Coming to Theory: Finding Foucault and Deleuze." In Feminist Engagements. Reading, Resisting, and Revisioning Male Theorists in Education and Cultural Studies, edited by Kathleen Weiler, 141-64. New York, NY: Routledge.

Sumara, Dennis, Brent Davis and Tammy Iftody. 2008. "101 Ways to Say 'Normal'." In Critical Readings in Teacher Education. Provoking Absences, edited by Anne M. Phelan and Jennifer Sumsion, 155-72. Rotterdam: Sense Publishers.

Taguchi, Hillevi Lenz. 2007. "Deconstructing and Transgressing the Theory - Practice Dichotomy in Early Childhood Education." Educational Philosophy \& Theory 39 (3): 275-90. doi: 10.1111/j.1469-5812.2007.00324.x

Thien, Deborah. 2005. "After or Beyond Feeling? A Consideration of Affect and Emotion in Geography." Area 37 (4): 450-454. doi:10.1111/j.1475-4762.2005.00643a.x.

Van Manen, Max. 1991. The Tact of Teaching: The Meaning of Pedagogical Thoughtfulness. Ontario: Althouse.

Wang, Hongyu. 2005. "Aporias, Responsibility, and the $\mathrm{Im} /$ possibility of Teaching Multicultural Education.” Educational Theory 55 (1): 45-60. doi: 10.1111/j.0013-2004.2005.00004.x

-. 2008. “"Red Eyes': Engaging Emotions in Multicultural Education.” Multicultural Perspectives 10 (1): 10-16. doi: 10.1080/15210960701869330

Zeichner, Ken. 2010. “Competition, Economic Rationalization, Increased Surveillance, and Attacks on Diversity: Neo-Liberalism and the Transformation of Teacher Education in the US." Teaching \& Teacher Education 26 (8): 1544-52. doi:10.1016/j.tate.2010.06.004

Zembylas, Michalinos. 2007a. "The Affective Politics of Hatred: Implications for Education." Intercultural Education 18 (3): 177-92. doi: 10.1080/14675980701463513

-. 2007b. "Emotional Capital and Education: Theoretical Insights from Bourdieu." British Journal of Educational Studies 55 (4): 443-63. doi: 10.1111/j.1467-8527.2007.00390.x

-. 2007c. "Theory and Methodology in Researching Emotions in Education." International Journal of Research \& Method in Education 30 (1): 57-72. doi: 10.1080/17437270701207785

—. 2010. “Teachers' Emotional Experiences of Growing Diversity and Multiculturalism in Schools and the Prospects of an Ethic of Discomfort." Teachers \& Teaching 16 (6): 703-16. doi: $10.1080 / 13540602.2010 .517687$

—. 2012. "The Politics of Fear and Empathy: Emotional Ambivalence in 'Host' Children and Youth Discourses About Migrants in Cyprus." Intercultural Education 23 (3): 195-208. doi: $10.1080 / 14675986.2012 .701426$ 
Lanas (2017) An argument for love in intercultural education in teacher education

Zembylas, Michalinos and Lynn Fendler. 2007. "Reframing Emotion in Education Through Lenses of Parrhesia and Care of the Self." Studies in Philosophy \& Education 26 (4): 319-33. doi: $10.1007 / \mathrm{s} 11217-007-9042-6$ 